\title{
Mating system and gene flow of Nothofagus alpina (Poepp. \& Endl.) Oerst. in a clonal seed orchard
}

\author{
Luz Cecilia García Cruzatty ${ }^{1,2,3^{*}}$, Ricardo Riegel ${ }^{4}$, Magaly Rivero ${ }^{5}$, Judith Carrasco ${ }^{4}$ and Fernando Droppelmann ${ }^{6}$
}

\begin{abstract}
Background: Understanding pathways of genetic information transfer from one generation to another is particularly important when open-pollinated seeds are collected for reforestation or for enrichment of native forests. Nothofagus alpina (Poepp. \& Endl.) Oerst. is native to temperate forests of southern Chile and Argentina. However, lack of knowledge of its reproductive biology has hampered its management in forest plantations and conservation of natural populations. Therefore, a clonal seed orchard of N. alpina in southern Chile was used to analyse the mating system and to estimate the number of pollen donors in this species.
\end{abstract}

Methods: The mating system was investigated using manual pollination tests on six clones, open-pollinated seeds were collected from four other clones to study gene flow and paternity analysis was done on progenies using microsatellite genetic markers. Pollen donors were inferred for 194 offspring of four adult trees using five microsatellite loci and an exclusion process.

Results: This species is exogamous and largely self-incompatible. The effective number of pollen donors found was 5 , which was less than the 19 expected theoretically. Results indicated that pollen flow in the seed orchard is deficient. This could be a result of limitations in the wind-pollination system, coupled with phenological dissynchrony among clones present.

Conclusions: $\mathrm{N}$. alpina is an exogamous, highly self-incompatible species. It does not reproduce through agamospermy, since there was no seed formation in the absence of pollen. Only a few trees contributed to the paternity of the progeny evaluated. This finding indicates that there exists a limited gene flow within the orchard due to reproductive isolation among genotypes.

Keywords: Paternity, Pollen, Anemophilous, Gene flow, Exogamy

\section{Background}

Mating system and gene flow are two mechanisms that allow a population of a species to maintain genetic variation. Such mechanisms facilitate adaptation to potentially changing environmental conditions, both in time and space (Boshier 2000). These mechanisms define the mode of genetic transmission between generations and govern the distribution of genetic variation not only within and

\footnotetext{
* Correspondence: cecilialuz29@hotmail.com

${ }^{1}$ Programa de Doctorado en Ciencias Forestales, Facultad de Ciencias Forestales y Recursos Naturales, Universidad Austral de Chile, Valdivia, Chile ${ }^{2}$ Facultad de Agronomía, Universidad Técnica de Manabí, Campus La Teodomira, Portoviejo, Manabí 130105, Ecuador

Full list of author information is available at the end of the article
}

among populations but also in effective population size and in the degree to which populations diverge due to natural selection or genetic drift (Holsinger 2000).

The term "mating system" refers to the pattern of crossing that a species exhibits to produce offspring; in other words, the manner in which populations of a particular species recombine their genes to create descendants. The type of mating system employed depends on both genetic and environmental factors (Seguí 2010). Genetic factors include genes that control self-incompatibility, sexual presentation system, reproductive maturity and endogamy depression while environmental factors influence flowering phenology and behaviour of pollinators. 
Gene flow refers to all the mechanisms that affect the movement of genes between populations (Slatkin 1994). Inter-population gene flow is one of the microevolutionary processes that directly affects the diversity and genetic structure of a plant population. Various studies have shown that a lack of effective pollen donors has negative effects on fitness of resulting populations (Dow and Ashley 1998; Burczyk et al. 2004).

Nothofagus alpina ${ }^{1}$ is native to temperate forests of southern Chile and Argentina and has the common name of raulí. This species has attracted the interest of scientists for its ecological importance and of timber producers around the world for the quality of its wood. However, lack of knowledge of its reproductive biology has hampered its management in forest plantations and conservation of natural populations. Therefore, the aim of the current study was to investigate the mating system and gene flow in $N$. alpina. Reproductive biology studies have been conducted in other Nothofagus species (Riveros et al. 1995), and these may serve as a useful model for $N$. alpina.

Seed orchards represent the link between reproductive biology and forestry based on genetic improvement. Seed orchards are expected to behave as panmitic populations, in Hardy-Weinberg equilibrium. They are established with the implicit assumption that desired genes, previously selected through phenotypic evaluation, will be effectively transmitted from the parental population to the offspring. However, some studies (Goto et al. 2002, Burczyk et al. 2004, Moriguchi et al. 2004) have suggested that this does not always occur. Hence, close examination of efficacy of seed orchards is of critical importance, as these determine genetic quality of future plantation stands.

Understanding how genetic information is transferred from one generation to the next is fundamental to ensuring diversity, particularly so when the intent is to collect open-pollinated seeds for reforestation or for enrichment of native forests. With this as background, our study used molecular markers to analyse the mating system and to calculate quantity of effective $N$. alpina donors in a clonal seed orchard.

Molecular markers are useful for the study of genetic movement at all levels. At the gene level, they are important for the study of genetic structure and gene flow within and between populations. Many studies have been conducted over the last decade using techniques based on molecular markers to analyse paternity and pollen dispersal (Goto et al. 2002; Burczyk et al. 2004; Moriguchi et al. 2004; Robledo-Arnuncio and Gil 2005; Torimaru et al. 2012; Wang et al. 2012).

\section{Methods}

The study was conducted at the Huillilemu $N$. alpina clonal seed orchard, located $65 \mathrm{~km}$ from the city of
Valdivia in the Los Ríos region of southern Chile $\left(39^{\circ} 32^{\prime}\right.$ $\left.56.57^{\prime \prime} \mathrm{S} ; 73^{\circ} 04^{\prime} 18.15^{\prime \prime} \mathrm{W}\right)$. This clonal seed orchard has a high degree of isolation from other native individuals of the same species since the natural distribution range of $N$. alpina corresponds to the south west of the Andean mountain range of Chile and Argentina. There are no plantations of this species in the area either so the clonal seed orchard also has a high degree of isolation from other planted individuals of the same species. The temperature in this area varies between a mean daily maximum of 23 to $26{ }^{\circ} \mathrm{C}$ in January (summer) and a mean daily minimum of 2.8 to $2.9^{\circ} \mathrm{C}$ in July (winter). Annual average precipitation is from 1300 to $1800 \mathrm{~mm}$. Accumulated annual growing degree days (base $7{ }^{\circ} \mathrm{C}$ ) vary between 865 and 1131, depending largely on elevation, and accumulated annual chill hours vary between 2100 and 2400 (Pérez and Ponce 2012).

This clonal seed orchard was established in 1989 and is composed of $N$. alpina individuals that originated from a wide elevational range in the Panguipulli area of the Andes (Additional files 1 and 2). All these trees are approximately the same age and height $(5-6 \mathrm{~m})$; nevertheless, phenological differences among individuals have been documented (García et al. 2013). The orchard is 3.1 ha in size and contains 33 clones, established at $5 \times 5 \mathrm{~m}$ spacing. The extent of canopy closure is approximately $60 \%$. Clones were obtained by grafting shoots of selected trees onto seedling rootstocks of the same species. The number of trees per clone varies between 1 and 48. These were randomly distributed within the orchard.

\section{Analysis of mating system through manual pollination}

Controlled crossing assays were conducted during 2012 season to obtain information on $N$. alpina reproduction and to compare and complement the information obtained using molecular analyses. For each assay, three to six branches of each selected clone were isolated and labelled, prior to flowering, for later pollination.

Assays were carried out in the Huillilemu seed orchard, following the method described by Ruiz-Zapata and Arroyo (1978) and Riveros et al. (1995), to determine the presence or absence of autogamy, allogamy and/or agamospermy. A sample consisted of $\operatorname{six} N$. alpina individuals. For each assay, branches containing from 10 to 84 inflorescences were used. These had previously been bagged in the budding phase to prevent natural pollination. Controlled pollinations were done at 1.5-2.0-m height.

Allogamy (C) was evaluated through cross-pollination, by placing fresh pollen from adjacent trees on receptive stigmas (of 11-84 inflorescences per branch). All male flowers had previously been removed from these branches to limit self-pollination. 
Autogamia (E) was evaluated by pollinating (10-36 inflorescences per branch) with fresh pollen from flowers of the same tree.

Agamospermy (A) was evaluated in female inflorescences on branches (12-36 female inflorescences per branch), on which male flowers had previously been removed to avoid self-pollination. Female inflorescences had also been previously bagged to avoid pollination by other trees. This isolation was maintained until the beginning of fruit development.

These assays enabled the type of mating system of this species to be determined. The self-incompatibility index was determined from seed/flower ratio resulting from manual self-pollination, divided by seed/flower ratio resulting from manual cross-pollination. Indices greater than 0.2 are deemed to indicate autogamy and genetic self-compatibility, with lower values indicating selfincompatibility (Ruiz-Zapata and Arroyo 1978).

Variables evaluated in each pollination assay were the percentage of viable seeds produced and percentage of empty seeds. Basic statistics calculated were means, standard deviations and variances. Additionally, a multiple comparison of proportion of seeds/flowers obtained in each treatment was carried out using the nonparametric Kruskal-Wallis test. One fruit is defined here as corresponding to one seed.

\section{Analysis of mating system and gene flow using molecular markers}

Four clones were selected from among those that flowered in 2011 season, from different locations within the orchard (Additional file 3). Selected trees were similar to base diameter, height, crown diameter and density. Selected trees flowered during period of peak flowering in orchard, so were surrounded by other flowering trees. In the "Map of the Huillilemu clonal seed orchard, 2011" (Additional file 3), the individuals that flowered during the study season are highlighted. A total of 56 trees, corresponding to 19 clones, flowered. In the current study, there were three individuals of clone 38 (5.4\%), two individuals of clone 361 (3.6\%), and one individual for both clone 34 and clone $40(1.8 \%)$.
Open-pollinated seeds were collected at $1.5-2.0-\mathrm{m}$ height (2-4 ramets per clone). To collect seed, plastic netting (mesh $2 \mathrm{~mm}$ ) was placed over 30 branches of a range of orientations, prior to fruit dehiscence. All the seed that had collected in nets was removed at the appropriate time, and empty seeds were separated from full ones. Full seeds were taken to a nursery and sown. For DNA extraction and molecular analyses, leaves were collected from the seedlings after 6 months (there were from 46 to 49 seedlings per mother tree). Leaves were also taken from the mother and several possible father trees (i.e. nearby trees that had flowered at the same time).

DNA was extracted from leaves of possible fathers (genotypes that flowered in the season), selected mothers and their associated seedlings, according to the methodology Lodhi et al. (1994), and this was amplified by PCR (polymerase chain reaction) at five nuclear microsatellite regions (P3', P5, P12, P23, P33, P34) (Table 1). These microsatellites (nSSRs) were developed at the Laboratorio de Biotecnología Silvoagrícola of Universidad Austral de Chile within the framework of FONDEF D10i1149 project.

Amplification was carried out in a final volume of $14 \mu \mathrm{L}$ with $1.4 \mathrm{ng}$ DNA, $0.28 \mu \mathrm{M}$ of each primer (except primer $\mathrm{P}^{\prime}$ ' for which $0.42 \mu \mathrm{M}$ was used), 1.2\% PVP, $0.15 \mathrm{mM}$ each dNTP, $1 \times$ buffer, $10 \times$ PCR buffer, $2.9 \mathrm{mM}$ $\mathrm{MgCl}_{2}$ and $0.5 \mathrm{U}$ of platinum Taq DNA polymerase.

A volume of $6 \mu \mathrm{L}$ of PCR product obtained was used to conduct agarose gel electrophoresis $(0.5 \%)$ to ensure successful amplification, and $4 \mu \mathrm{L}$ was sent to Dr Hiroshi Takamine of CENEREMA laboratory of Molecular Markers $^{2}$ at the Universidad Austral of Chile, where automated capillary electrophoreses was carried out using a Genetic Analyser/Applied Biosystems sequencer. The genotype of each individual was determined from these electropherograms using GeneMarker V2.4.2 software (SoftGenetics, USA).

Characterisation of the reproductive system was done by estimating the reproductive parameters: outcrossing rate, rate of uniparental endogamy (self-fertilisation), rate of biparental endogamy (crossing between genetically related individuals) and correlated paternity. The

Table 1 Microsatellite regions sequences used in DNA amplification of Nothofagus alpina

\begin{tabular}{lllll}
\hline Primer code & Forward primer sequence & Reverse primer sequence & Fluorophore colour & Size (bp) \\
\hline P3' & 5TGC GCA TAA ACA ACA AAC CAC 3' & Hex + 5'GTG TCG CTG TGC TAG CTT C 3' & Green & 164-186 \\
P5 & Tet + 5'CCT GCG TCC TAG TाT GAG AAG 3' & 5'GCA CTG AGA GCA CTT GTT GTG 3' & Green & 110-124 \\
P12 & 5'GCC GCA TGA TCC CAA TAA AAT G 3' & Tet + AGG GAG CGC CTA TCC TTA AC 3' & Green & 134-150 \\
P23 & 5'AAG AGG CTG CCC TCA ACT C 3' & Fam + 5'ACA GCC TTC CCT AAC TCA GC 3' & Blue & 156-180 \\
P33 & Fam + 5'GCA GGG TTG ACT GTT GCT TC 3' & 5'AAC AGC CAT CTT TTA CCT TGC 3' & Blue & 228-250 \\
P34 & 5'GAG AGA CTC ACC GGG TाT GG 3' & Fam + 5'GCA GCC ATT CAC TGA TTC ACC 3' & Blue & $124-144$ \\
\hline
\end{tabular}


estimation of reproductive parameters and assignment of parents to evaluated progeny was done using the Colony 2.0 program, based on results obtained from nSSRs (Jones and Wang 2010).

Estimates of self-fertilisation and biparental inbreeding were performed using different methods: full likelihood and pairwise likelihood score combined (multiple descendants are compared simultaneously), deviation from the Hardy-Weinberg equilibrium for self-fertilisation and biparental inbreeding, and identity disequilibrium for selffertilisation (genetic markers are assumed to be in linkage equilibrium and Hardy-Weinberg equilibrium) (Jones and Wang 2010).

To carry out the reconstruction of pedigree, we considered the molecular signatures of all possible parents of the progeny, the maternal molecular signature and the molecular signatures of the progenies. The sample was split into three subsamples: an offspring sample, a candidate father sample and a candidate mother sample. Offspring in the three subsamples were categorised as full-sibs (sharing both parents), half-sibs (sharing a single parent) or unrelated (sharing no parents). The candidate father sample comprised all individuals that were potential fathers (trees that flowered during the season). In this case, the mother was known so this genotype was directly entered (Jones and Wang 2010).

Heterozygosity, observed alleles, effective alleles and genetic diversity were calculated using the Population Genetic Analysis (POPGENE) program, version 1.32 (Yeh et al. 1997). The comparison of heterozygosity and genetic diversity estimated for parents and observed in progeny was carried out using the chi-square test.

\section{Results}

The manual pollination test results showed a selfincompatibility index (SII) of 0.094 . There was adequate seed formation through cross-pollination, and a low percentage of seeds obtained through manual self-pollination. The production of full seeds from manual cross-pollination varied among different trees evaluated, ranging from 0.31 to 0.49 full seeds per flower, whereas the range obtained in individuals that were manually self-pollinated was less than or equal to $5.1 \%$ (Table 2).

Very few clones contributed to fertilisation. Only five of the 19 clones that flowered during the period of study contributed to 193 paternities; both male and female parents were included, since self-fertilisation rates were seen in ranges of 8.16 to $14.89 \%$ (Table 3 ).

The effective number of fathers of progeny from the given mothers evaluated here varied between two (which corresponds to $10.53 \%$ of the total number of trees that flowered during the season) and three (which corresponds to $15.79 \%$ of the total number of trees that flowered during the season). In the sample studied, $87.75 \%$ of progeny from tree 34 were fertilised by clone 40 (paternal probability $>0.99$ ), while the remaining $12.25 \%$ was the product of selffertilisation. Two parents were assigned to progeny of tree 38 , tree 11 (40.43\%) and tree $46(44.68 \%)$; the remaining $14.86 \%$ was the product of self-fertilisation (Table 3 ).

This paternity designation gave rise to progenies constituted by half-siblings and full-siblings (including siblings resulting from self-fertilisation). Accordingly, most descendants were full-siblings for three of the four mothers evaluated (Fig. 1). Rates of correlated paternities were greater than 0.70 in three of the progeny evaluated, with an average of 0.66 for the species, under conditions evaluated (Fig. 1, Table 3).

Values obtained by full likelihood (FL) and combined pairwise likelihood score (PLS) and deviation from the Hardy-Weinberg equilibrium (DHW) for selfing (S) were similar among clones and similar to the sample average, i.e. between 10.64 and $16.33 \%$ for FL-PLS and between 12.33 and $15.86 \%$ for DHW. However, there is a discrepancy in these values compared with those obtained through identity disequilibrium (ID), where values of selfing between 0 and $9 \%$ were obtained. The average biparental endogamy (E) was calculated to be $7.21 \%$, varying between 5.62 and $8.89 \%$ with FL-PLS and between 6.57 and $8.62 \%$ with DHW (Table 4).

The observed heterozygosity (Ho) in clones flowering during the 2011 season averaged 0.73 (Table 5). It was between 0.60 and $0.69(\overline{H o}=0.64)$ for open-pollinated progeny; that is, it decreased by as much as $12.3 \%$ for the adult trees that were evaluated. Both the average number of alleles found (6) and effective allele number (3) were lower in the progeny evaluated compared with the values calculated for the 19 adults (eight and five alleles, respectively) that flowered. The genetic diversity in progeny was estimated to be 0.67 , i.e. $16.25 \%$ lower than the genetic diversity of adult trees (which was calculated to be 0.80 ).

When analysing the progenies together, the values of genetic diversity, observed heterozygosity and number of effective alleles were smaller compared with the values of possible parents, but higher than when analysing the individual progenies (Table 5).

\section{Discussion}

$N$. alpina is a species that exhibits a high degree of self-incompatibility $(\mathrm{SII}=0.094)$, but it does allow a degree of self-fertilisation. This characteristic has been described previously for other species of the genus Nothofagus (Riveros et al. 1995; Torres and Puntieri 2013) and also for some other species less closely related (Yacine and Bouras 1997). In the mating system of $N$. alpina, protandry encourages cross-pollination (García et al. 2013), despite hermaphroditism. Also in $N$. alpina, there is a spatial separation of male and 
Table 2 Number of empty and full seeds following self-fertilisation (E), agamospermy (A), cross-fertilisation (C). The self-incompatibility index (SII) was calculated

\begin{tabular}{|c|c|c|c|c|c|}
\hline Individual treatments (clones) & Pollinated flowers & $\bar{x}$ full seeds ${ }^{a}$ & Full seeds/flower ${ }^{b}$ & $\bar{x}$ empty seeds & $\mathrm{SIIE} E / C^{c}$ \\
\hline \multicolumn{6}{|l|}{ Self-fertilisation (E) } \\
\hline 26 & 185 & 5.26 & $0.029 \mathrm{a}$ & 179.74 & 0.06 \\
\hline 11 & 82 & 2.95 & $0.035 \mathrm{~b}$ & 79.05 & 0.078 \\
\hline 32 & 107 & 3.85 & $0.036 \mathrm{~b}$ & 103.15 & 0.07 \\
\hline 36 & 106 & 3.89 & $0.036 \mathrm{~b}$ & 102.11 & 0.08 \\
\hline 5 & 80 & 3.68 & $0.046 \mathrm{bc}$ & 76.32 & 0.15 \\
\hline 19 & 123 & 6.27 & $0.051 \mathrm{c}$ & 116.73 & 0.12 \\
\hline $\bar{x}$ & & & 0.039 & & 0.09 \\
\hline $\mathrm{Sd}$ & & & 0.01 & & 0.03 \\
\hline$\sigma^{2}$ & & & 0 & & 0 \\
\hline \multicolumn{6}{|l|}{ Agamospermy (A) } \\
\hline 32 & 113 & 0 & 0 & 113 & \\
\hline 36 & 144 & 0 & 0 & 144 & \\
\hline 19 & 190 & 0 & 0 & 190 & \\
\hline 5 & 153 & 0 & 0 & 153 & \\
\hline 19 & 106 & 0 & 0 & 106 & \\
\hline $\bar{x}$ & & & 0 & & \\
\hline$S d$ & & & 0 & & \\
\hline$\sigma^{2}$ & & & 0 & & \\
\hline \multicolumn{6}{|l|}{ Cross-fertilisation (C) } \\
\hline 26 & 234 & 111.38 & $0.46 \mathrm{~b}$ & 122.62 & \\
\hline 11 & 68 & 31.95 & $0.47 b$ & 36.05 & \\
\hline 32 & 480 & 234.96 & $0.49 \mathrm{cb}$ & 245.04 & \\
\hline 36 & 95 & 42.74 & $0.45 b$ & 52.26 & \\
\hline 5 & 86 & 26.66 & $0.31 \mathrm{a}$ & 59.34 & \\
\hline 19 & 240 & 101.25 & $0.42 \mathrm{a}$ & 135.75 & \\
\hline $\bar{x}$ & & & 0.43 & & \\
\hline$S d$ & & & 0.0661 & & \\
\hline$\sigma^{2}$ & & & 0.0043 & & \\
\hline
\end{tabular}

${ }^{a}$ Means for three replicate branches per tree

${ }^{b}$ Different letters signify statistical differences according to the Kruskal-Wallis test $C$ ( $\left.k=8.87, p=0.1810\right), E=(k=6.75, p=0.2210)$

${ }^{\mathrm{C}}$ Ratio of full seeds per flower between $\mathrm{E}$ and $\mathrm{C}$

female flowers, with male flowers at basal axil of the shoot and female flowers at apical axil (Puntieri et al. 2009; García et al. 2013).

It has generally been assumed that temporal and spatial separation of genders in Nothofagus species prevents selffertilisation (Riveros et al. 1995; Donoso et al. 2006). Although, according to our results, cross-fertilisation predominates, it has also been noted that these barriers are not enough to prevent self-fertilisation, resulting in a proportion of progeny that are the product of selffertilisation. Moreover, García et al. (2013) reported a temporal overlap between the opening of male and female flowers on an individual tree, which could result in self- fertilisation. This interpretation has been corroborated by Torres and Puntieri (2013) based on similarities between N. alpina and N. obliqua.

Torres and Puntieri (2013) reported a high degree of self-incompatibility in $N$. alpina based on low production of full seeds and a low percentage of pollen grains germinating on stigmas following manual selffertilisation. However, the few seeds obtained through self-pollination germinated and produced seedlings just as efficiently as those resulting from cross-pollination. Based on this result, the self-incompatibility barrier seems to be pre-zygotic, since pollen is rejected on stigmatic surface. The low production of full seeds 
Table 3 Inferred paternities, effective numbers of pollen donors (Nep) and estimates of correlated paternity (Pcr) for progeny of open pollination of four mother trees, based on microsatellite markers

\begin{tabular}{lllllll}
\hline 9 Mother & o Inferred father & $N^{a}$ & $\%$ & Probability (95\%) & Nep & $\mathrm{Pcr}^{b}$ \\
\hline 34 & P34 (self) & 6 & 12.25 & $>0.99$ & 2 & 0.72 \\
& P40 & 43 & 87.75 & $>0.99$ & & \\
34 & P11 & 19 & 40.43 & 0.961 & & \\
& P38 (self) & 7 & 14.89 & $>0.99$ & 3 & 0.37 \\
& P46 & 21 & 44.68 & 0.910 & & \\
40 & P34 & 42 & 85.71 & $0.95-0.98$ & & \\
& P40 (self) & 4 & 8.16 & $>0.99$ & 2 & 0.77 \\
361 & P34 & 43 & 87.76 & $>0.99$ & & \\
& P361 (self) & 4 & 8.16 & $>0.99$ & 2 & 0.78 \\
\hline
\end{tabular}

${ }^{\mathrm{a}}$ Number of offspring identified

${ }^{b}$ Correlated paternity is the proportion of siblings to half siblings

obtained following self-pollination is likely a result of the low number of pollen grains germinating

The paternity of progeny (as determined using microsatellite markers) resulting from open pollination indicates that there was a greater degree of self-fertilisation in this seed orchard than reported in previous studies with other Nothofagus species. Self-fertilisation was even greater than expected from manual pollination assays in current study. This estimate of selfing rate might have been inflated by undetected biparental endogamy, present in N. alpina, as in many other populations that exhibit partial selffertilisation. This issue can result in an overestimation of self-fertilisation, since it has a similar effect on homozygosity of this parameter (Wang et al. 2012).

In our $N$. alpina seed orchard, differences among trees in reproductive phenophases limits cross-pollination. Added to this effect is the high degree of temporal overlap of male and female flowers in an individual tree (García et al. 2013), which could result in higher numbers than expected of self-pollen accumulating on stigmas relative to cross-pollen in natural population. Following this line of reasoning, it is possible that that cross-pollination is more common in a natural forest with better synchronisation of flowering among individuals, and hence better pollen flow, than in our seed orchard. However, the selfing rates are not high enough to raise concerns about inbreeding, and the selfing rates could be lowered by collecting seed from genotypes with high self-incompatibility. Furthermore, research on Eucalyptus globulus Labill. has shown that the selfing rate can be lower in the upper parts of the canopy (Patterson et al. 2004).

The source data show that clones 38 and 11, and also 361 and 34 (mothers and fathers, respectively), were obtained from trees growing relatively close (altitudinally 80 and $130 \mathrm{~m}$, respectively) to each other in a mountain forests (Additional file 2). This natural proximity may indicate that gene flow exists between nearby trees and that this natural pattern also occurs in the seed orchard. However, no source data are available for tree 40, which was found to be a mother tree and was also assigned as a father tree for progeny of tree 34. Hence, data available here are too limited to confirm this suggestion, but García et al. (2013) found that a strong overlap of reproductive phenophases occurred between trees sourced from areas experiencing similar conditions of elevation, soil, rainfall, etc. These results are also in agreement with those of Premoli and Mathiasen (2011) who found that phenological differences observed at various elevations, reinforced by diversifying selection, could explain reproductive isolation between adjacent populations. This pattern of crossing could offer an evolutionary advantage of maintaining important characteristics for adaptation to different soil and weather conditions in the wide range of elevations where this species is naturally distributed. According to Futuyma (1998) and Eguiarte (2009), knowledge of gene flow is fundamental to understanding the degree to which different populations of a species function as independent evolutionary units and thus determining if a species evolves randomly (by genetic drift) or if it responds in an adaptive manner (by natural selection).

Genetic variation in forest species is well known in relation to a wide geographical distribution and associated differences in environment (Alía et al. 2003). In the case of the seed orchard studied here (which has a limited pollen flow), it is important that crossings be properly planned so as to conserve dispersive processes and hence outcrossing. Such planning is fundamental if loss of variability in small populations is to be avoided.

The number of effective pollen donors (Nep) for individuals evaluated in seed orchard was less than the number expected theoretically. In other seed-orchard studies, where deviations in panmixia have also been established, effective pollination patterns have been attributed to factors such as genetic distances between clones, variations in pollen produced and phenological synchrony between clones (Goto et al. 2002; Moriguchi et al. 2004). Nevertheless, the number of effective pollen donors detected in this study (Nep 2-3) was less than that registered in seed orchards of other species. For example, in the related species Quercus macrocarpa Michx in a plot within the McHenry County farm near Harvard, IL, Dow and Ashley (1996) evaluated 62 adults and 100 seedlings and determined that only four of these 62 trees were fathers of about 75 of seedlings. This trend has also been shown for anemophilous gymnosperms, such as Pseudotsuga menziesii (Mirb.) Franco (Nep 5.7-11.0, Burczyk and Prat 1997), Picea abies (L.) H.Karst. (Nep 6.7, Burczyk et al. 2004) and Pinus sylvestris L. (Nep 12.2, Torimaru et al. 2012).

The limited gene flow observed in the seed orchard in this study is supported by García et al. (2013) who used 


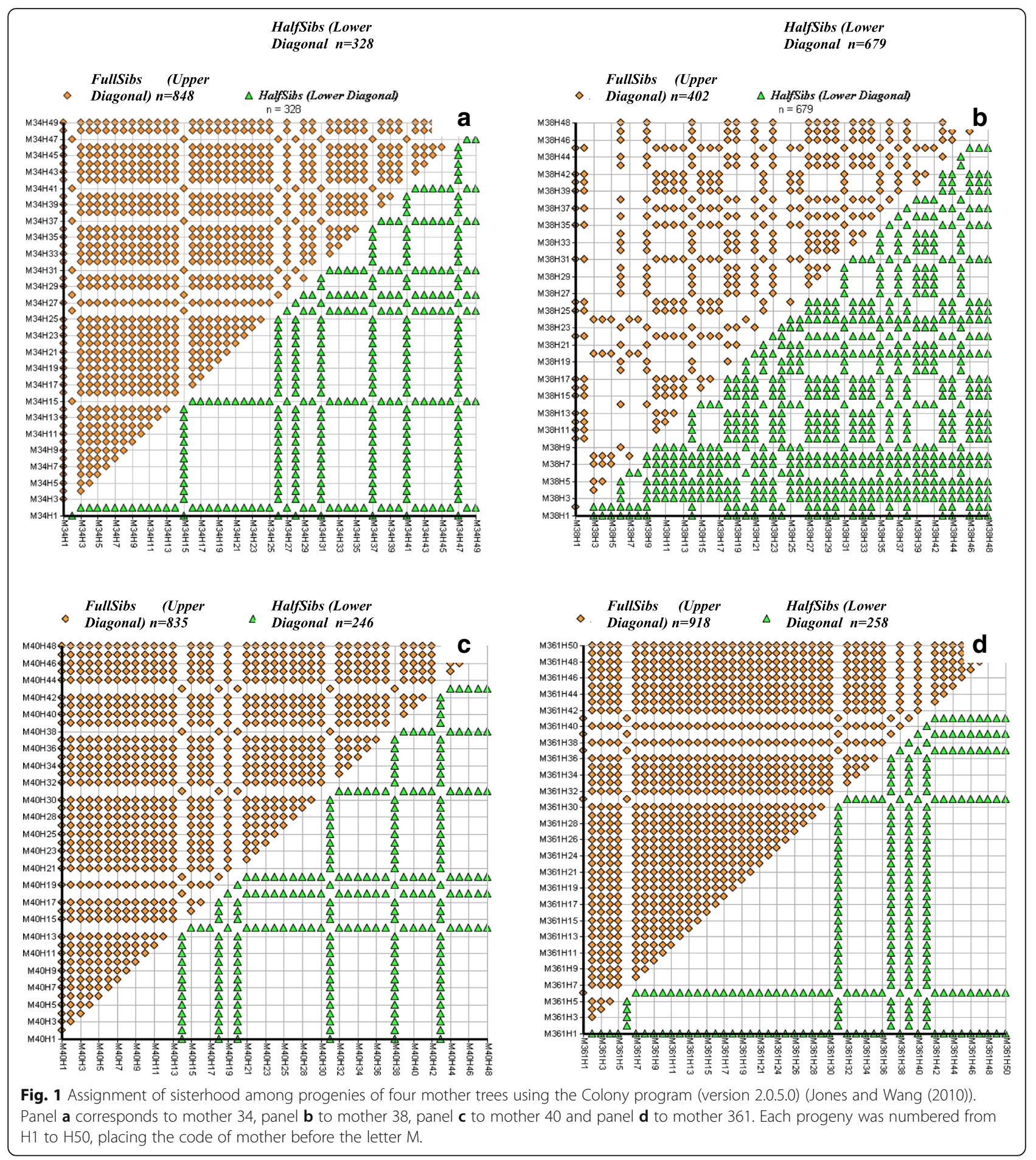

phenological data to calculate a very low general index of overlap (0.22) among various individuals. These authors also explained the existence of individuals that have a greater probability of crossing, such as trees 38 and $11(0.60)$, which were also analysed in current study (tree 38 as a mother, with $40.43 \%$ of its progeny having tree 11 as the male parent).
Estimated rates of paternity correlation indicate that progeny of open pollination from different mother trees present a high proportion of full-siblings $(\bar{x}=0.70)$. This means that seeds produced by one tree originate from a small reproductive population, with pollen originating from only a few parents (varying from 2 to 3 ). This will result in progeny having different degrees of 
Table 4 Rates of selfing (S) and biparental endogamy (E) of open-pollinated progeny of four mother trees, estimated by methods: full likelihood (FL) and pairwise likelihood score (PLS) combined, deviation from Hardy-Weinberg equilibrium (DHW) for self-fertilisation and biparental inbreeding, and identity disequilibrium (ID) for self-fertilisation

\begin{tabular}{|c|c|c|c|c|c|}
\hline \multirow{2}{*}{ 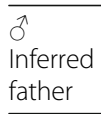 } & \multirow[b]{2}{*}{ Parameter } & \multicolumn{2}{|c|}{ FL-PLS } & \multirow[b]{2}{*}{ DHW } & \multirow[b]{2}{*}{ ID } \\
\hline & & $\overline{\bar{x}}$ & $C^{a}$ & & \\
\hline \multirow{2}{*}{34} & $E$ & 0.089 & $0.029-0.157$ & 0.068 & \\
\hline & S & 0.163 & $0.056-0.271$ & 0.127 & 0.080 \\
\hline \multirow{2}{*}{38} & E & 0.081 & $0.002-0.173$ & 0.086 & \\
\hline & S & 0.149 & $0.003-0.295$ & 0.159 & 0.091 \\
\hline \multirow{2}{*}{40} & E & 0.056 & $0.013-0.129$ & 0.066 & \\
\hline & S & 0.106 & $0.026-0.229$ & 0.123 & 0.069 \\
\hline \multirow{2}{*}{361} & E & 0.065 & $0.011-0.126$ & 0.069 & \\
\hline & S & 0.122 & $0.021-0.223$ & 0.128 & 0.000 \\
\hline \multirow{2}{*}{$\bar{x}$} & E & 0.073 & & 0.072 & \\
\hline & S & 0.135 & & 0.134 & 0.060 \\
\hline
\end{tabular}

${ }^{a}$ Confidence intervals. Estimates are given for confidence intervals (95\%) for FL-PLS

kinship, such as half siblings, full-siblings and siblings of self-fertilisation.

Streiff et al. (1999) conducted paternity studies in Quercus suber L. and Quercus petraea (Matt.) Liebl. and determined an excess of close crossings and a preferred pollination direction in seven of the 13 progeny examined. Their study was conducted in naturally regenerated lots, sample trees were 120 years old and microsatellites were used for paternity analysis.

Crossings between closely related individuals must be considered a mate-selection strategy for conserving characteristics that will allow tree adaptation within microclimates. This theory supports the concept that it is crucial to study of mating systems of a species, its phenological behaviour and efficient fertilisation before initiating activities related to establishment of conservation lots, seed banks and seed orchards. Otherwise, individuals used may become reproductively isolated.

Seed orchards are usually established to supply genetically improved material for breeding individuals that have been selected for their phenotypes. However, seed obtained from these orchards can be considered better than seed from unimproved populations only if the crossing between superior trees within the seed orchard is efficacious, that is, if seed production from breeding represents an ideal situation in which all clones contribute equally to generation of seeds. According to this study, equal contribution of all clones to the seed produced does not occur. Instead, seedling progeny represent only a small proportion of possible crosses within seed orchard. This is very far from the ideal of panmixia. It is likely due to phenological differences and other types of incompatibilities among individuals. Understanding genetic variation and the mating system of $N$. alpina in seed-orchard management will allow better planning for controlled crossings in a second phase of a breeding programme.

Numerous studies in coniferous seed orchards have shown a similar trend, which has been attributed mainly to among-parent variation in fecundity and phenology (Jonsson et al. 1976; Gömöry et al. 2003; Mariette et al. 2007). More tests on these "plus" trees in clonal plantations have resulted in selection of a number of clone cultivars selected for their adaptation to various soil and climate situations, growth patterns, shape and resistance to disease.

\section{Conclusions}

$N$. alpina is an exogamous species that exhibits a high degree of self-incompatibility, but it does allow a low degree of self-fertilisation. This species does not reproduce through agamospermy, since there was no seed formation in the absence of male gametes. Only a few trees contributed to the paternity of the progeny evaluated. This indicates that there exists a limited gene flow

Table 5 Parameters of allele numbers per locus ( $N$, number of effective alleles (Ne), heterozygosity observed (Ho) and genetic diversity of Nei (DN) for 19 adults that flowered during 2011 and progeny of four trees

\begin{tabular}{|c|c|c|c|c|c|c|c|c|c|c|c|c|c|c|c|c|c|c|c|c|c|c|c|c|}
\hline \multirow{2}{*}{ Locus } & \multicolumn{4}{|c|}{ Adults (possible fathers) } & \multicolumn{4}{|c|}{ Progeny $34^{a}$} & \multicolumn{4}{|c|}{ Progeny 38} & \multicolumn{4}{|c|}{ Progeny 40} & \multicolumn{4}{|c|}{ Progeny 361} & \multicolumn{4}{|l|}{ Mix } \\
\hline & $N$ & $\mathrm{Ne}$ & $\mathrm{Ho}$ & DN & $N$ & $\mathrm{Ne}$ & $\mathrm{Ho}$ & DN & $N$ & $\mathrm{Ne}$ & $\mathrm{Ho}$ & DN & $N$ & $\mathrm{Ne}$ & $\mathrm{Ho}$ & DN & $N$ & $\mathrm{Ne}$ & $\mathrm{Ho}$ & DN & $N$ & $\mathrm{Ne}$ & $\mathrm{Ho}$ & DN \\
\hline 34 & 8 & 6.22 & 0.74 & 0.84 & 6 & 3.38 & 0.76 & 0.70 & 5 & 2.99 & 0.79 & 0.67 & 6 & 3.99 & 0.85 & 0.75 & 7 & 3.17 & 0.75 & 0.69 & 11 & 4.45 & 0.86 & 0.87 \\
\hline 23 & 9 & 4.66 & 0.79 & 0.79 & 8 & 3.55 & 0.76 & 0.72 & 6 & 2.58 & 0.79 & 0.62 & 7 & 2.36 & 0.66 & 0.58 & 8 & 2.65 & 0.80 & 0.62 & 13 & 3.19 & 0.79 & 0.69 \\
\hline 33 & 8 & 4.43 & 0.74 & 0.77 & 6 & 3.35 & 0.59 & 0.70 & 5 & 2.30 & 0.36 & 0.56 & 4 & 2.88 & 0.43 & 0.65 & 4 & 2.47 & 0.31 & 0.60 & 11 & 2.80 & 0.43 & 0.64 \\
\hline 12 & 10 & 5.97 & 0.95 & 0.83 & 7 & 2.53 & 0.59 & 0.61 & 7 & 3.55 & 0.72 & 0.72 & 6 & 3.76 & 0.83 & 0.73 & 5 & 3.39 & 0.90 & 0.71 & 12 & 4.70 & 0.85 & 0.79 \\
\hline 3 & 7 & 3.99 & 0.42 & 0.75 & 3 & 1.97 & 0.31 & 0.49 & 7 & 3.13 & 0.81 & 0.68 & 5 & 1.77 & 0.30 & 0.43 & 5 & 2.31 & 0.47 & 0.57 & 13 & 3.00 & 0.51 & 0.67 \\
\hline $\bar{x}$ & 8.4 & 5.05 & 0.73 & 0.80 & 6.0 & 2.96 & 0.60 & $0.64^{*}$ & 6.0 & 2.91 & 0.69 & $0.65^{*}$ & 5.6 & 2.95 & 0.61 & 0.63 & 5.8 & 2.80 & 0.64 & $0.64^{*}$ & 12 & 3.63 & 0.68 & 0.71 \\
\hline $\mathrm{Sd}$ & 1.14 & 0.99 & 0.19 & 0.04 & 1.87 & 0.68 & 0.18 & 0.10 & 1.00 & 0.49 & 0.19 & 0.06 & 1.14 & 0.93 & 0.24 & 0.13 & 1.64 & 0.46 & 0.25 & 0.06 & 1.0 & 0.88 & 0.20 & 0.10 \\
\hline
\end{tabular}

Asterisks indicate statistical differences; progeny $34 j i^{2}=2591 p<0.9923$; progeny $38 j^{2}=0.1925 p<0.9957$; progeny $361 j i^{2}=0.2045 p<0.9951$

${ }^{\mathrm{a}}$ The heterozygosity and genetic diversity of each of progeny was compared individually with values calculated for parents 
within the orchard due to reproductive isolation among genotypes.

\section{Endnotes}

${ }^{1} \mathrm{~A}$ number of names have been applied to this species including Fagus alpina Poepp. Endl., Nov. Gen. Sp. Pl. 2: 69 (1838); Fagus procera Poepp. Endl., Nov. Gen. Sp. Pl. 2: 69 (1838); Fagus nervosa Phil. Linnaea 29: 43 (1858); Nothofagus procera Oerst., Bidr. Egefam.: 24 (1872); Nothofagus alpina (Poepp. et Endl.) Oerst. (1872); and Nothofagus nervosa (Phil.) Krasser, Ann. K. K. Naturhist. Hofmus. 11: 163 (1896) (Royal Botanic Gardens 2012). Lennon et al. (1987) suggested that the correct name should be $N$. nervosa (Phil.) and that the term "alpine" should be applied to the progeny of $N$. nervosa $\times N$. obliqua. However, the name $N$. nervosa has not been recognised by the Society of Botany in Chile, so recently, García et al (2013) used the synonym $N$. alpina for the same species. At the time of writing, the internationally renowned taxonomic database, The Plant List (http:// www.theplantlist.org/), states that the accepted name of this species is Nothofagus alpina (Poepp. \& Endl.) Oerst. so this name will be used here.

${ }^{2}$ Centro Nacional de Capacitación y entrenamiento en Reproducción y Manejo Animal de la Universidad Austral de Chile

\section{Additional files}

Additional file 1: Origin of Nothofagus alpina clones that were used in trials in the season 2012, Huillilemu seed orchard. (DOCX 11 kb)

Additional file 2: Origin of Nothofagus alpina clones that bloomed in the 2011 season, Huillilemu seed orchard. Three of four mother trees were analysed, and two trees designated as parents are indicated (there is no data of origin for trees 40 and 46). Tree 34 was analysed as a mother and father designated as the progeny of tree 40. (DOCX $12 \mathrm{~kb}$ )

Additional file 3: Map of the "Huillilemu" clonal seed orchard, 2011. (DOCX $233 \mathrm{~kb}$ )

\section{Acknowledgements}

The authors would like to thank the FONDEF D10i1149 project for funding needed to conduct this research. Luz García would also like to acknowledge the support of MECESUP UCO0702 and SENESCYT (Secretaría de Ciencia y Tecnología del Ecuador) for the doctoral scholarships during this study.

\section{Authors' contributions}

LGC conducted the fieldwork and laboratory during doctoral studies and carried out the wording. RR advised on the application of molecular tools and was involved in the analysis of the molecular data. MR helped make the controlled crosses and respective analysis of the mating system of Nothofagus alpina. JC helped perform the different tasks in molecular biology laboratory and collaborated in drafting the text. FD was involved in the analysis and discussion of the data obtained. All authors read and approved the final manuscript.

\section{Competing interests}

The authors declare that they have no competing interests.

\section{Publisher's Note}

Springer Nature remains neutral with regard to jurisdictional claims in published maps and institutional affiliations.

\section{Author details}

${ }^{1}$ Programa de Doctorado en Ciencias Forestales, Facultad de Ciencias Forestales y Recursos Naturales, Universidad Austral de Chile, Valdivia, Chile.

${ }^{2}$ Facultad de Agronomía, Universidad Técnica de Manabí, Campus La Teodomira, Portoviejo, Manabí 130105, Ecuador. ${ }^{3}$ Facultad de Ciencias Ambientales, Universidad Técnica Estatal de Quevedo, Quevedo, Los Ríos, Ecuador. ${ }^{4}$ Facultad de Ciencias Agrarias, Universidad Austral de Chile, Valdivia, Chile. ${ }^{5}$ Cooperativa de Mejoramiento Genético de Chile, Valdivia, Chile. ${ }^{6}$ Facultad de Ciencias Forestales y Recursos Naturales, Universidad Austral de Chile, Valdivia, Chile.

Received: 8 June 2016 Accepted: 29 May 2017

Published online: 29 June 2017

\section{References}

Alía, R., Agúndez, D., Alba, N., González, S., Soto, A. (2003). Variabilidad genética y gestión forestal. Ecosistemas 2003/3 (URL: https://www.revistaecosistemas. net/index.php/ecosistemas/article/view/230).

Boshier, D. H. (2000). Mating systems. In D. Boshier \& A. Young (Eds.), Forest conservation genetics: principles and practice (pp. 6-79). Collingwood, Australia: CSIRO Publishing.

Burczyk, J. L., \& Prat, D. (1997). Male reproductive success in Pseudotsuga menziesii (Mirb.) Franco: the effects of spatial structure and flowering characteristics. Heredity, 79, 638-647.

Burczyk, J. L., Lewandowski, A., \& Chalupka, W. (2004). Local pollen dispersal and distant gene flow in Norway spruce (Picea abies [L.] Karst.). Forest Ecology and Management, 197, 39-48.

Donoso, P. J., Donoso, C., Marchelli, P., Gallo, L., Escobar, B. (2006). Nothofagus nervosa (Phil.) Dim. et Mil. In Donoso, C. (Ed.). Las especies arbóreas de los bosques templados de Chile y Argentina. Autoecología. Ediciones Marisa Cuneo

Dow, B. D., \& Ashley, M. V. (1996). Microsatellite analysis of seed dispersal and parentage of saplings in bur oak, Quercus macrocarpa. Molecular Ecology, 5, 615-627.

Dow, B. D., \& Ashley, M. V. (1998). Factors influencing male mating success in bur oak, Quercus macrocarpa. New Forests, 15, 161-180.

Eguiarte, L. E. (2009). Nueva guía para principiantes a la genética de poblaciones. En: Morrone J., Magaña P. (editores). Evolución Biológica. Facultad de Ciencias, UNAM, D.F., México, p. 83- 102

Futuyma, D. J. (1998). Evolutionary biology (3rd ed.). Sunderland MA, USA: Sinauer Associates Inc

García, L. C., Droppelmann, F. E., \& Rivero, M. (2013). Morfología y fenología floral de Nothofagus nervosa (Nothofagaceae) en un huerto semillero clonal en la región de Los Ríos, Chile. Bosque, 34(2), 221-231.

Gömöry, D., Bruchanik, R., \& Longauer, R. (2003). Fertility variation and flowering asynchrony in Pinus sylvestris: consequences for the genetic structure of progeny in seed orchards. Forest Ecology and Management, 174, 117-126.

Goto, S., Miyahara, F., \& Ide, Y. (2002). Identification of the male parents of half-sib progeny from Japanese black pine (Pinus thunbergii Parl.) clonal seed orchard using RAPD markers. Breeding Science, 52, 71-77.

Holsinger, K. E. (2000). Reproductive systems and evolution in vascular plants. Proceedings of the National Academy of Sciences USA, 97, 7037-7042.

Jones, O. R., \& Wang, J. (2010). Colony: a program for parentage and sibship inference from multilocus genotype data. Molecular Ecology Resources, 10, 551-555. Computer Program Note.

Jonsson, A., Ekberg, I., \& Eriksson, G. (1976). Flowering in a seed orchard of Pinus sylvestris L. Studia Forestalia Suecica, 135, 1-38.

Lennon, J. A., Martín, E. S., Stevens, R. A., \& Wigston, D. L. (1987). Nothofagus nervosa (Phil.) Dim. et Mil. The correct name for raulí, Chilean southern beech (N. procera). Arboricultural Journal, 11, 323-332

Lodhi, M. A., Ye, G.-N., Weeden, N. F., \& Reisch, B. I. (1994). A simple and efficient method DNA extraction from grapevine cultivars and Vitis species. Plant Molecular Biology Reporter, 12, 6-13.

Mariette, S., Balsemin, E., Stoeckel, Tavaud, M., Le Bouler, H., Santi, F., \& Verger, M. (2007). Parental participation in progeny and effective population sizes in experimental seed orchards of wild cherry Prunus avium L. (Batsch). Annals of Forest Science, 64, 533-539. 
Moriguchi, Y., Taira, H., Tani, N., \& Tsumura, Y. (2004). Variation of paternal contribution in a seed orchard of Cryptomeria japonica determined using microsatellite markers. Canadian Journal of Forest Research, 34, 1683-1690.

Patterson, B., Vaillancourt, R. E., Pilbeam, D. J., \& Potts, B. M. (2004). Factors affecting variation in outcrossing rate in Eucalyptus globulus. Australian Journal of Botany, 52, 773-780

Pérez, C., Ponce, R. (Eds) (2012). Guía para el uso de la información agroclimática en el manejo de cultivos y frutales. Instituto de Investigaciones Agropecuarias INIA, Fundación de Desarrollo Frutícola FDF y Unidad Nacional de Emergencias Agrícolas y Gestión del Riesgo Agroclimático UNEA.

Premoli, A. C., Mathiasen, P. (2011). Respuestas ecofisiológicas adaptativas y plásticas en ambientes secos de montaña: Nothofagus pumilio, el árbol que acaparó los Andes Australes. Ecología Austral, 21(3), 251-269 (URL: http://www.scielo.org.ar/pdf/ecoaus/v21n3/v21n3a03.pdf).

Puntieri, J. G., Grosfeld, J., \& Heuret, P. (2009). Preformation and distribution of staminate and pistillate flowers in flowers in growth units of Nothofagus nervosa and N. obliqua (Nothofagaceae). Annals of Botany, 103, 411-421.

Riveros, M., Paredes, M., Rosas, M., Cárdenas, E., Armesto, J., \& Arroyo, M. T. K. (1995). Reproductive biology in species of the genus Nothofagus. Environmental and Experimental Botany, 35, 519-524.

Robledo-Arnuncio, J. J., \& Gil, L. (2005). Patterns of pollen dispersal in a small population of Pinus sylvestris $L$. revealed by total exclusion paternity analysis. Heredity, 94, 13-22.

Royal Botanic Gardens. 2012. Nothofagus alpina, Kew: world checklist of selected plant families. Retrieved 18 March 2012.

Ruiz-Zapata, T., \& Arroyo, M. T. K. (1978). Plant reproductive ecology of a secondary deciduous forest in Venezuela. Biotropica, 10, 221-230.

Seguí, J. M. (2010). Biología y Biotecnología reproductiva de las plantas. Editorial Universidad Politécnica de Valencia.

Slatkin, M. W. (1994). Gene flow and population structure. In: Ecological Genetics (ed Real LA), p. 3-18. Princeton University Press.

Streiff, R., Ducousso, A., Lexer, C., Steinkellner, H., Gloessl, J., \& Kremer, A. (1999). Pollen dispersal inferred from paternity analysis in a mixed oak stand of Quercus robur L. and Q. petraea (Matt.) Liebl. Molecular Ecology, 8, 831-841.

Torimaru, T., Wennstro, U., Lindgren, D., \& Wang, X. R. (2012). Effects of male fecundity, interindividual distance and anisotropic pollen dispersal on mating success in a Scots pine (Pinus sylvestris) seed orchard. Heredity, 108, 312-321.

Torres, C. D., Puntieri, J. G. (2013). Pollination and self-interference in Nothofagus. Flora http://ac.els-cdn.com/S0367253013000741/1-s2.0-S0367253013000741main.pdf?_tid=86012f74-4998-11e7-a5ab-00000aab0f01\&acdnat= 1496630689_40b746d63cc2e8c8193decb80d05e616

Wang, J., Yousry, A., El-Kassaby, Y., \& Ritland, K. (2012). Estimating selfing rates from reconstructed pedigrees using multilocus genotype data. Molecular Ecology, 21, 100-116.

Yacine, A., \& Bouras, F. (1997). Self- and cross-pollination effects on pollen tube growth and seed set in holm oak Quercus ilex L. (Fagaceae). Annals of Forest Science, 54, 447-462.

Yeh, F. C., Yang, R. C., Boyle T. B., Ye Z. H., Mao J. X., Yang R., Boyle T., Ye Z. (1997) POPGENE. The User- Friendly Shareware for Population Genetic Analysis. Molecular Biology and Biotechnology Centre. University of Alberta. Canada (URL: https://sites.ualberta.ca/ fyeh/popgene.pdf).

\section{Submit your manuscript to a SpringerOpen ${ }^{\circ}$ journal and benefit from:}

- Convenient online submission

- Rigorous peer review

- Open access: articles freely available online

- High visibility within the field

- Retaining the copyright to your article

Submit your next manuscript at $\boldsymbol{\nabla}$ springeropen.com 